\title{
Konflik Penambangan Batugamping Kecamatan Ponjong dalam Tinjauan Arena Bourdieu
}

\author{
Hilary Reinhart ${ }^{1}$ \\ Magister Pengelolaan Lingkungan, Sekolah Pascasarjana \\ Universitas Gadjah Mada, Yogyakarta, Indonesia
}

Artikel Masuk : 27 Desember 2016

Artikel Diterima : 20 Maret 2017

Tersedia Online : 27 Maret 2017

\begin{abstract}
Abstrak: Penambangan batugamping merupakan suatu permasalahan di kawasan batugamping karena menyebabkan degradasi lingkungan, perubahan sosial agraris menuju industri, dan terjadinya konflik antar pemangku kepentingan. Sebagai suatu permasalahan, penambangan batugamping tidak hanya perlu dipandang sebagai permasalahan kerusakan lingkungan, melainkan juga permasalahan pengelolaan lingkungan. Artikel bertujuan untuk memberikan gambaran terhadap konflik penambangan di kawasan karst. Di sisi lain, studi ini juga memberikan pendekatan baru dalam memahami konflik pertambangan. Studi dilakukan menggunakan analisis deskriptif kualitatif. Analisis dilakukan menggunakan pemetaan pemangku kepentingan dan potensi konflik yang terjadi antar pemangku kepentingan. Hasil pemetaan tersebut kemudian dikontekstualisasi menggunakan teori praktis sosial yang menggunakan pendekatan arena (field) dan kapital (capital) dari Pierre Bourdieu. Pendekatan tersebut digunakan untuk memahami arah konflik dan kontestasi oleh setiap aktor. Dari analisis kapital, didapatkan bahwa pemerintah, yaitu bidang Energi dan Sumber Daya Mineral di berbagai level birokrasi memiliki kapital yang paling dominan dalam arena penambangan batugamping di Kecamatan Ponjong karena memiliki kapital paling lengkap dan mengungguli aktor lain. Dapat disimpulkan bahwa perbedaan jenis kapital mempengaruhi aktor mengambil posisi dalam suatu arena dan masing-masing aktor yang memiliki kapital berupaya mengakumulasi kapital untuk mencapai kapital utama.
\end{abstract}

Kata kunci: arena, kapital, konflik, pemangku kepentingan, Teori Bourdieu

\begin{abstract}
Limestone mining is a problem in the karst area because it causes environmental degradation, social change from the agrarian to industrial, and conflicts among stakeholders. Therefore, the limestone mining is not only identified as the environmental damage problems but also environmental management problems. The article aimed to explain an overview of the mining conflicts in the karst region. On the other hand, this study also provided a new approach in understanding the conflicts of mining. The study was conducted using qualitative descriptive analysis. Analyses were performed using stakeholder mapping and potential conflicts between stakeholders. The mapping results were contextualized using field and capital approach of Pierre Bourdieu theory. The approach used to understand the direction of conflicts and capital contestation of each author. The capital analysis showed that the government, namely the Energy and Mineral
\end{abstract}

\footnotetext{
${ }^{1}$ Korespondensi Penulis: Magister Pengelolaan Lingkungan, Sekolah Pascasarjana, UGM, Yogyakarta, Indonesia Email: reinharthilary@gmail.com
} 
Resources in various levels of bureaucracy has the dominant capital in the arena of limestone mining in Ponjong District because it has a complete capital and outperforms of the other actors. It concludes that the differences types of capital affect the actors to take the position in an arena and each actor who has a robust capital sought to accumulate the capital to attain the main capital.

Keywords: field, capital, conflict, stakeholders, Bourdieu Theory

\section{Pendahuluan}

Kawasan Desa Bedoyo di Kecamatan Ponjong adalah salah desa di Kabupaten Gunungkidul yang memiliki potensi tambang batugamping. Penambangan di Desa Bedoyo, Kecamatan Ponjong, Kabupaten Gunungkidul merupakan suatu permasalahan tersendiri di kawasan karst Gunung Sewu. Status Gunung Sewu yang ditetapkan sebagai kawasan konservasi geologi menyebabkan kegiatan penambangan batugamping pada dasarnya tidak diizinkan. Penetapan Gunung Sewu sebagai suatu kawasan konservasi diatur pada Keputusan Menteri Energi dan Sumber Daya Mineral Nomor 1659.K/40/MEM/2004 tentang Penetapan Kawasan Karst Gunung Sewu dan Pacitan Timur yang kemudian diperkuat dengan terbitnya Peraturan Pemerintah Nomor 26 Tahun 2008 tentang Rencana Tata Ruang Wilayah Nasional. Kedua peraturan tersebut mengamanatkan untuk melindungi kawasan karst sebagai kawasan lindung geologi.

Penambangan batugamping di kawasan Desa Bedoyo dimulai pada tahun 1980 diawali dengan aktivitas eksplorasi oleh PT Imporan yang melakukan survey batugamping di Desa Karangasem. Pada tahun-tahun berikutnya, perusahaan-perusahaan lain kemudian mulai masuk ke kawasan tersebut, seperti PT Supersonik, PT Kembang Jeruk, PT Sugih Alam Perkasa, dan PT Anindya. Pertimbangan-pertimbangan dilakukannya penambangan pada kawasan Desa Bedoyo antara lain karena (1) kualitas batugamping yang memenuhi kriteria, (2) jumlah cadangan banyak, (3) aksesiblitas mudah, dan (4) penduduk Desa Bedoyo masih banyak yang tergolong miskin sehingga penyerapan tenaga kerja oleh pabrik dapat membantu perekonomiannya (Satmoko, 2005). Sementara itu, menurut Widyastuti (2007), penambangan batugamping di Desa Bedoyo terjadi karena faktor pendorong, yaitu 1) Bahan baku, dimana cadangan batugamping di Bedoyo cukup besar dan memenuhi persyaratan, yaitu mencapai $2.465 .607 \mathrm{~m}^{3}, 2$ ) tenaga kerja, dimana masyarakat butuh perkejaan terutama di musim kemarau ketika lahan warga menjadi tidak produktif karena kekurangan air, 3) luas lahan pertanian masyarakat yang sempit membuat masyarakat harus mencari mata pencaharian aternatif, dan 4) pendapatan sektor pertanian.

Perizinan penambangan di Desa Bedoyo dibedakan menjadi, yakni Surat Izin Penambangan Daerah (SIPD), Surat Izin Penambangan Rakyat (SIPR), dan Penambangan Tanpa Izin (PETI). Namun demikian, penelitian Wuspada, Purnaweni, dan Sasongko (2012) mengindikasikan bahwa masih terdapat ketidaktegasan pemerintah daerah dalam menegur penambangan ilegal di kawasan karst meskipun Pemerintah Kabupaten Gunungkidul cukup serius menolak memberikan izin usaha penambangan batu gamping di kawasan karst sejak tahun 2009. Ini dikarenakan pelarangan penambangan kawasan karst akan memberikan dampak tersendiri bagi kondisi perekonomian daerah-daerah yang memiliki kawasan karst. Daerah-daerah tersebut akan kehilangan Pendapatan Asli Daerah dari penambangan kawasan karst apabila larangan tersebut diberlakukan. Selain itu, pemasukan bagi masyarakat yang bekerja pada sektor penambangan kawasan karst akan berkurang. Hal ini menjadikan pemerintah daerah gamang dalam memutuskan pemanfaatan kawasan karst. Di samping itu, ternyata inventarisasi kawasan karst yang belum menyeluruh dan lengkap juga belum dilakukan untuk semua daerah (Hasil wawancara dengan Disperindagkoptam ESDM Kabupaten Gunungkidul, 2014). 
Secara sederhana, pengelolaan lingkungan harus mencakup tiga hal, yaitu (1) identifikasi tujuan, (2) menentukan apakah tujuan tersebut dapat dicapai, dan (3) implementasi dengan pengembangan maksud tersebut. Sementara itu, masalah pengelolaan lingkungan yang rentan terjadi adalah masyarakat yang kurang mengetahui kebutuhan mereka. Pada kasus Kecamatan Ponjong pada khususnya dan kawasan karst pada umumnya, terjadi evaluasi status perizinan penambangan batugamping. Pemerintah daerah menggunakan dasar PP Nomor 26 Tahun 2008 yang menyatakan bahwa seluruh kawasan karst adalah kawasan lindung sehingga harus menghentikan segala bentuk kegiatan penambangan batugamping. Hal tersebut menimbulkan dilema tersendiri karena banyak daerah yang mendapatkan sumber pendapatan dari penambangan batugamping.

Berdasarkan kerangka pengelolaan yang demikian, seorang manajer lingkungan bertugas untuk dapat mengalahkan publik dan berbagai kelompok kepentingan. Pada kasus penambangan gamping di Kabupaten Gunungkidul, manajer lingkungan berada di tingkat eksekutif atau dinas yang berada di bawah Pemerintah Kabupaten Gunungkidul. Dalam mencapai tujuan manajer lingkungan digunakan 3 pendekatan (Barrow, 1999), yaitu 1) pendekatan nasihat yang menggunakan pendidikan demonstrasi, media, atau pariwarapariwara, 2) pendekatan ekonomi atau fiskal, melalui pajak, hutang dan bantuan, subsidi, dan perjanjian dagang, atau 3) pendekatan peraturan, melalui standar, monitoring dan pembatasan, lisensi, dan zonasi.

Pengelolaan lingkungan kawasan karst merupakan pengelolaan multidisiplin karena banyaknya nilai di kawasan karst (Samodra, 2001) dan pemanfaatan kawasan karst (Sutikno, 2001). Oleh sebab itu, maka pengelolaan kawsan karst perlu melibatkan banyak pemangku kepentingan yang bertindak menurut persepsi dan nilai utama yang mereka anut. Pendekatan arena Bourdieu dibutuhkan untuk melihat konflik dari sisi persepsi dan praktis sosial para pemangku kepentingan tersebut. Pendekatan arena Bourdieu dianggap mampu untuk memetakan dorongan-dorongan dalam suatu lingkup kajian tertentu karena menjelaskan mengenai relasi-relasi/ interaksi antar aktor yang berada dalam suatu lingkup kajian sosial (Walther, 2014; Moore, 2009; Benson, 1999; Bourdieu, 1977).

Permasalahan penambangan batugamping di Kecamatan Ponjong merupakan sebuah konflik manajemen lingkungan. Hal tersebut dapat dilihat dari bagaimana relasi antar aktor-aktor dalam suatu arena sesuai dengan pendekatan Bourdieu. Relasi konflik tersebut berkaitan dengan "habitus" yang terjadi dalam arena dan membentuk praktikpraktik sesuai dengan persamaan [(habitus) (capita)] + arena = praktis (Bourdieu, 1996: 101). Arena merupakan suatu ruang kontestasi tempat para aktor tersebut mendominasi kapital-kapital tertentu. Posisi aktor dalam arena tersebut ditentukan oleh bobot dan jenis kapital yang dimiliki (Adib, 2012). Perbedaan jenis kapital yang dimiliki oleh setiap aktor menjadi langkah aktor dalam mengambil posisi dalam suatu arena atau disebut sebagai pengambilan-posisi dan di area penelitian, kapital yang paling berpengaruh adalah kapital kultural yang hadir dalam penyusunan yang disatukan dalam institusi tertentu (incorporated disposition) (Brubaker, 1985).

Melihat urgensi perlunya memahami konflik pada kawasan pertambangan yang menyangkut kepentingan berbagai aktor tersebut, maka dirumuskan permasalahan penelitian, yaitu mengapa terjadi kasus konflik penambangan batugamping di Kecamatan Ponjong pasca dikeluarkannya peraturan pemerintah terkait status kawasan karst dan bagaimana kasus tersebut terjadi dalam konteks arena Bourdieu? Dengan demikian, studi ini bertujuan untuk memberikan gambaran terhadap konflik penambangan di kawasan karst. Selain itu, penelitian ini juga bertujuan untuk memberikan pendekatan baru dalam memahami konflik pertambangan yang terjadi. 


\section{Metode Penelitian}

Penelitian ini merupakan penelitian deskriptif kualitatif. Penelitian dibatasi pada analisis kelembagaan. Pengumpulan data dilakukan melalui teknik studi pustaka dengan menggunakan data-data sekunder dari studi literatur dan sumber tertulis lainnya lalu diinterpretasikan dengan menggunakan hasil wawancara dan temuan lapangan. Data-data sekunder merupakan data yang didapat dari studi literature dan sumber-sumber tertulis lainnya. Analisis data dilakukan secara kualitatif. Analisis dilakukan menggunakan pemetaan pemangku kepentingan dan potensi konflik yang terjadi antar pemangku kepentingan. Hasil pemetaan tersebut kemudian dikontekstualisasi menggunakan teori praktis sosial yang menggunakan pendekatan arena (field) dan kapital (capital) dari Pierre Bourdieu. Oleh karena penelitian dilakukan untuk memetakan posisi aktor-aktor bersangkutan dalam arena penambangan batugamping, maka penelitian hanya dilaksanakan ketika terjadi transisi perubahan status kawasan karst.

Pendekatan yang dilakukan adalah pendekatan ekologi politik. Studi ekologi politik berkaitan dengan pembagian kekuasaan. Pemetaan aktor-aktor yang terlibat hingga kepada konflik yang terjadi dilakukan dengan menggunakan matriks-matriks fungsi pengawasan lingkungan dan matriks relasi antar lembaga. Dari pembuatan matriks tersebut, pengembangan relasi dan konflik kemudian dilakukan dengan menganalisis persepsi setiap pemangku kepentingan atau para aktor atau pihak-pihak yang berkepentingan dalam penambangan batugamping di Kecamatan Ponjong, meliputi pemerintah, swasta, dan masyarakat. Pada penelitian ini, pendekatan ekologi politik yang digunakan adalah pendekatan subjek lingkungan, dimana pendekatan ini mengkaji kepengaturan (governmentality). Pada pendekatan ini, hal-hal yang menjadi perhatian pada pendekatan ini adalah nilai terhadap lingkungan merupakan hasil institusi politik.

Pendekatan ekologi politik yang dilakukan lalu dijabarkan dengan menggunakan teori sosial praktis Pierre Bourdieu (Bourdieu, 1977; Moore, 2009). Teori praktik sosial Bourdieu merupakan teori sosiologis yang menjelaskan mengenai relasi-relasi antar aktor yang berada dalam suatu lingkup kajian sosial. Konsep arena sendiri mencakup analisis berbagai faktor yang mendorong setiap aktor di dalam arena tersebut mengambil posisi, baik secara ekonomi maupun kultural (Benson, 1999). Dalam penelitian ini diambil lingkup penambangan batugamping sebagai suatu arena dalam konteks Bourdieu. Ini dikarenakan pendekatan arena Bourdieu dapat memetakan dorongan-dorongan dalam suatu lingkup kajian tertentu. Dorongan tersebut pada masa awal pemikiran Bourdieu dikenal sebagai 'habitus' (Couldry, 2003). Untuk memahami prinsip pengelolaan lingkungan dan konflik yang terjadi, maka pemahaman terhadap aktor atau pemangku kepentingan dan cara berpikirnya di lingkup konflik tersebut mutlak diperlukan. Penggunaan arena akan memudahkan pemahaman mengenai interaksi aktor-aktor yang berada dalam lingkup konflik yang tengah diamati termasuk dalam konteks pengelolaan lingkungan (Walther, 2014).

\section{Hasil dan Pembahasan}

\section{Studi Persepsi Stakeholder}

Persepsi stakeholder merupakan salah satu metode yang penting dalam melakukan analisis kelembagaan dalam suatu permasalahan. Tindakan dan perilaku setiap stakeholder sangat dipengaruhi oleh konstruksi persepsi pada masing-masing stakeholder itu sendiri (Cahyono \& Susanti, 2014). Tindakan dan perilaku para stakeholder tersebut yang kemudian menjadi dasar utama dalam dinamika konflik yang dapat dilihat dan dirasakan. Dari studi persepsi ini juga dapat dipetakan bagaimana konflik yang terjadi secara garis besar. 
Pemetaan persepsi yang dilakukan Cahyono dan Susanti (2014) menunjukan bahwa terdapat pro kontra antar dua kelompok organisasi besar, yaitu masyarakat dengan perusahaan penambang yang menginginkan kegiatan ekstraktif sebagai sumber mata pencaharian dan pemerintah yang berfungsi sebagai organisasi yang mengkonservasi kawasan sesuai dengan tugas pokok dan fungsinya. Tabel 1 menunjukkan pemetaan persepsi para stakeholder.

\section{Tabel 1. Persepsi Stakeholder terhadap Penambangan Batugamping}

\begin{tabular}{|c|c|c|}
\hline No & Stakeholder & Persepsi \\
\hline 1 & Penambang & $\begin{array}{ll} & \text { Batugamping merupakan anugerah Tuhan sehingga boleh diambil } \\
\text { - } & \text { Tambang memberikan penghasilan dalam waktu yang singkat } \\
\text { - } & \text { Penambangan telah ada sebelum peraturan pelarangan berlaku }\end{array}$ \\
\hline 2 & $\begin{array}{l}\text { Pemilik lahan } \\
\text { tambang }\end{array}$ & Ingin mengubah bentuk lahan untuk kepentingan lain \\
\hline 3 & Bappeda & $\begin{array}{l}\text { - Melindungi kawasan karst sebagai ekosistem yang rapuh } \\
\text { - Berusaha mencari mata pencaharian alternatif untuk para } \\
\text { penambang eksisting }\end{array}$ \\
\hline 4 & $\begin{array}{l}\text { Dinas Pertambangan } \\
\text { dan Energi }\end{array}$ & $\begin{array}{l}\text { - Hasil pertambangan yang tidak memiliki izin tidak menyumbang } \\
\text { PAD } \\
\text { - Perlindungan terhadap kawasan karst } \\
\text { - } \text { Penambangan tidak boleh di dalam kawasan karst }\end{array}$ \\
\hline 5 & $\begin{array}{l}\text { Dinas Kehutanan dan } \\
\text { Perkebunan }\end{array}$ & $\begin{array}{l}\text { - Reklamasi pasca tambang } \\
\text { - Penambangan karst tidak boleh dalam kawasan karst }\end{array}$ \\
\hline 6 & Pemerintah daerah & $\begin{array}{l}\text { - Tidak ada lagi yang diizinkan menambang semenjak tahun } 2009 \\
\text { - Seperti Bappeda kesulitan mencari alterative pekerjaan bagi para } \\
\text { penambang }\end{array}$ \\
\hline 7 & $\begin{array}{l}\text { Organisasi Sosial } \\
\text { Masyarakat }\end{array}$ & $\begin{array}{l}\text { - Tambang gamping merusak lingkungan sehingga tidak boleh } \\
\text { beroperasi kembali }\end{array}$ \\
\hline 8 & Perusahaan tambang & - Mengikuti ketentuan dari pemerintah apabila memang harus ditutup \\
\hline
\end{tabular}

\section{Organisasi dalam Penambangan Kapur}

Organisasi atau aktor atau pemangku kepentingan yang ada di arena penambangan batugamping di Kecamatan Ponjong dapat dilihat di Tabel 2. Aktor yang berkepentingan dalam penambangan batugamping ada 3 , yaitu pemerintah (pusat, provinsi, dan kabupaten), pihak swasta, dan masyarakat.

Tabel 2. Organisasi dalam Penambangan Batugamping

\begin{tabular}{lll}
\hline \multicolumn{1}{c}{ Pemerintah } & \multicolumn{1}{c}{ Swasta } & \multicolumn{1}{c}{ Masyarakat } \\
\hline $\begin{array}{l}\text { Pusat } \\
\text { - Kementrian Energi dan Sumber Daya Mineral }\end{array}$ & $\begin{array}{l}\text { Perusahaan } \\
\text { tambang }\end{array}$ & Penambang rakyat \\
$\quad$ (ESDM) & & \\
- Badan Geologi Nasional & & Organisasi Sosial \\
Provinsi & Masyarakat \\
- Keraton & \\
- Dinas ESDM Provinsi DIY & \\
Kabupaten & & \\
- Disperindagkop ESDM Kabupaten Gunungkidul & \\
- Badan Perencanaan Pembangunan Daerah & \\
$\quad$ (Bappeda) Kabupaten Gunungkidul & \\
\hline Sumber: Analisis Penulis, 2016
\end{tabular}


Organisasi dan aktor dalam konflik penambangan batugamping memiliki fungsi manajemen dan kegiatan lingkungan hidup. Tabel 3 dan Tabel 4 menjelaskan masingmasing penjabaran dari fungsi-fungsi tersebut. Penjabaran demikian akan menunjukan bagaimana tugas pokok fungsi dari masing-masing aktor dan organisasi.

Dari matriks pada Tabel 3, terlihat bahwa jumlah setiap fungsi yang dimiliki oleh setiap organisasi berkisar di jumlah 2-4 fungsi dengan lingkup kegiatan utama pada pengorganisasian, koordinasi, kegiatan dan evaluasi. Hal tersebut menunjukan tidak terlihatnya dominasi secara fungsi pada suatu organisasi tertentu. Meskipun demikian, organisasi yang menjadi cukup dominan adalah Disperindagkop ESDM Kabupaten Gunungkidul dengan menjalankan 7 fungsi yang mencakup fungsi perencanaan, pengorganisasian, perintah, koordinasi, kegiatan, pengawasan, dan evaluasi.

Fungsi koordinasi mendapatkan total yang cukup tinggi, dimana terdapat 7 organisasi yang melaksanakannya, mencakup Kementerian ESDM dan Badan Geologi Nasional pada lingkup pusat, pihak keraton dan Dinas ESDM Provinsi DIY pada lingkup provinsi, dan Disperindagkop ESDM Kabupaten Gunungkidul, Bappeda Kabupaten Gunungkidul, dan perusahaan tambang. Hal tersebut menunjukan baiknya interaksi antar lembaga. Namun demikian, fungsi koordinasi yang dilakukan oleh para pemangku kepentingan belum melibatkan penambang rakyat yang notabene merupakan aktor yang jumlahnya paling besar. Oleh sebab itu, kegiatan penambangan masih terjadi dan sebagian besar dilakukan oleh penambang rakyat.

Hal lain yang juga perlu diperhatikan bahwa terjadi tumpang tindih dalam fungsi lingkungan untuk masing-masing pemangku kepentingan. Upaya yang dilakukan untuk tumpang tindih fungsi tersebut adalah dengan melakukan koordinasi untuk menentukan teknis pelaksanaan fungsi lingkungan. Selain itu, untuk fungsi seperti perintah dan pengawasan, tumpang tindih tidak terjadi karena fungsi tersebut dijalankan secara hirarkis.

Dari matriks pada Tabel 4, dapat terlihat bagaimana kegiatan yang dilakukan masingmasing organisasi terkait dengan kegiatan lingkungan hidup. Hal tersebut menunjukan kegiatan pada penambangan umumnya dilakukan oleh pemerintah tingkat kabupaten dan akar rumput. Birokrat pada tingkat, seperi Badan Geologi Nasional dan Dinas ESDM Provinsi DIY atas hanya berfungsi pada tingkatan pengawasan dan tidak terlibat langsung di dalam kegiatan lingkungan hidup yang dilakukan. Hal tersebut menunjukan bagaimana pusaran konflik berada pada tataran pemerintah kabupaten dan akar rumput. Kegiatan yang menjadi pusat pusaran konflik yang terjadi Kecamatan Ponjong adalah kegiatan pemanfaatan, pengembangan, dan pemeliharaan. Ini dikarenakan ketiga kegiatan tersebut memiliki skor paling tinggi, dimana cukup banyak aktor yang terlibat di dalamnya.

Gambar 1 menunjukkan matrik konflik antar stakeholder. Dari asumsi relasi yang dilakukan pada matriks pada Gambar 1 relasi terlihat suatu pola yang jelas. Konflik paling banyak terjdi antara dua organisasi, yaitu Badan Geologi Nasional dan Organisasi Sosial Masyarakat. Sesuai dengan asumsi yang dibuat, kedua organisasi tersebut merupakan organisasi yang merasa harus mencegah dan melarang penambangan terjadi di kawasan batugamping. Sementara organisasi sisanya dapat dikelompokan sebagai organisasi yang mendukung penambangan tetap diizinkan untuk dilakukan.

Apabila dibandingkan dengan persepsi yang ada pada setiap stakeholder, maka asumsi yang ada pada matriks pada Tabel 4 sesuai pada organisasi sosial masyarakat karena organisasi sosial masyarakat menghendaki penambangan agar dihentikan. Sementara itu pemerintah, dalam hal ini dinas-dinas terkait memiliki sikap mendua dalam penambangan batugamping. 
Tabel 3. Matriks Fungsi Lingkungan

\begin{tabular}{|c|c|c|c|c|c|c|c|c|c|}
\hline \multirow{2}{*}{$\begin{array}{c}\text { Organisasi Lingkungan } \\
\text { Hidup }\end{array}$} & \multicolumn{8}{|c|}{ Manajemen Lingkungan Hidup } & \multirow[b]{2}{*}{ Tota } \\
\hline & Perencanaan & Pengorganisasian & Perintah & Koordinasi & Kegiatan & Pengawasan & Evaluasi & Regulasi & \\
\hline \multicolumn{10}{|c|}{ Pemerintah Pusat } \\
\hline Kementerian ESDM & & & $\mathrm{V}$ & $\mathrm{V}$ & & & & $\mathrm{v}$ & 3 \\
\hline Badan Geologi Nasional & & & & V & & V & V & & 3 \\
\hline \multicolumn{10}{|c|}{ Provinsi } \\
\hline Keraton & & & & V & & & V & $\mathrm{v}$ & 3 \\
\hline Dinas ESDM Provinsi & & V & V & $\mathrm{V}$ & & $\mathrm{V}$ & & & 3 \\
\hline \multicolumn{10}{|c|}{ Kabupaten } \\
\hline Disperindagkop ESDM & V & V & V & V & V & V & V & & 7 \\
\hline Bappeda & $\mathrm{V}$ & & & $\mathrm{V}$ & $\mathrm{V}$ & & & & 3 \\
\hline Perusahaan Tambang & & V & & V & V & & & & 3 \\
\hline Penambang Rakyat & & V & & & $\mathrm{V}$ & & & & 2 \\
\hline Organisasi Sosial Masyarakat & & & & & & V & V & & 2 \\
\hline & 2 & 4 & 3 & 7 & 4 & 3 & 4 & 2 & \\
\hline
\end{tabular}

Tabel 4. Matriks Kegiatan Lingkungan

\begin{tabular}{|c|c|c|c|c|c|c|c|}
\hline \multirow{2}{*}{ Organisasi Lingkungan Hidup } & \multicolumn{7}{|c|}{ Kegiatan Lingkungan Hidup } \\
\hline & Penataan & Pemanfaatan & Pengembangan & Pemeliharaan & Pemulihan & Total & Keterangan \\
\hline \multicolumn{8}{|c|}{ Pemerintah Pusat } \\
\hline Kementerian ESDM & V & & & & & 1 & \\
\hline Badan Geologi Nasional & & & $\mathrm{V}$ & $\mathrm{V}$ & & 2 & \\
\hline \multicolumn{8}{|c|}{ Provinsi } \\
\hline Keraton & & & & & & & \\
\hline Dinas ESDM Provinsi & $\mathrm{V}$ & $\mathrm{V}$ & & & & 2 & Pemanfaatan lewat PAD \\
\hline \multicolumn{8}{|c|}{ Kabupaten } \\
\hline Disperindagkop ESDM & V & $\mathrm{V}$ & $\mathrm{V}$ & $\mathrm{V}$ & & 4 & Pemanfaatan lewat PAD \\
\hline Bappeda & V & & & & & 1 & \\
\hline Perusahaan Tambang & & $\mathrm{V}$ & $\mathrm{V}$ & $\mathrm{V}$ & $\mathrm{V}$ & 4 & Ekstraksi \\
\hline Penambang Rakyat & & $\mathrm{V}$ & $\mathrm{V}$ & $\mathrm{V}$ & & 3 & Ekstraksi skala kecil \\
\hline \multirow[t]{2}{*}{ Organisasi Sosial Masyarakat } & & & & $\mathrm{V}$ & & 1 & \\
\hline & 4 & 4 & 4 & 5 & 1 & & \\
\hline
\end{tabular}




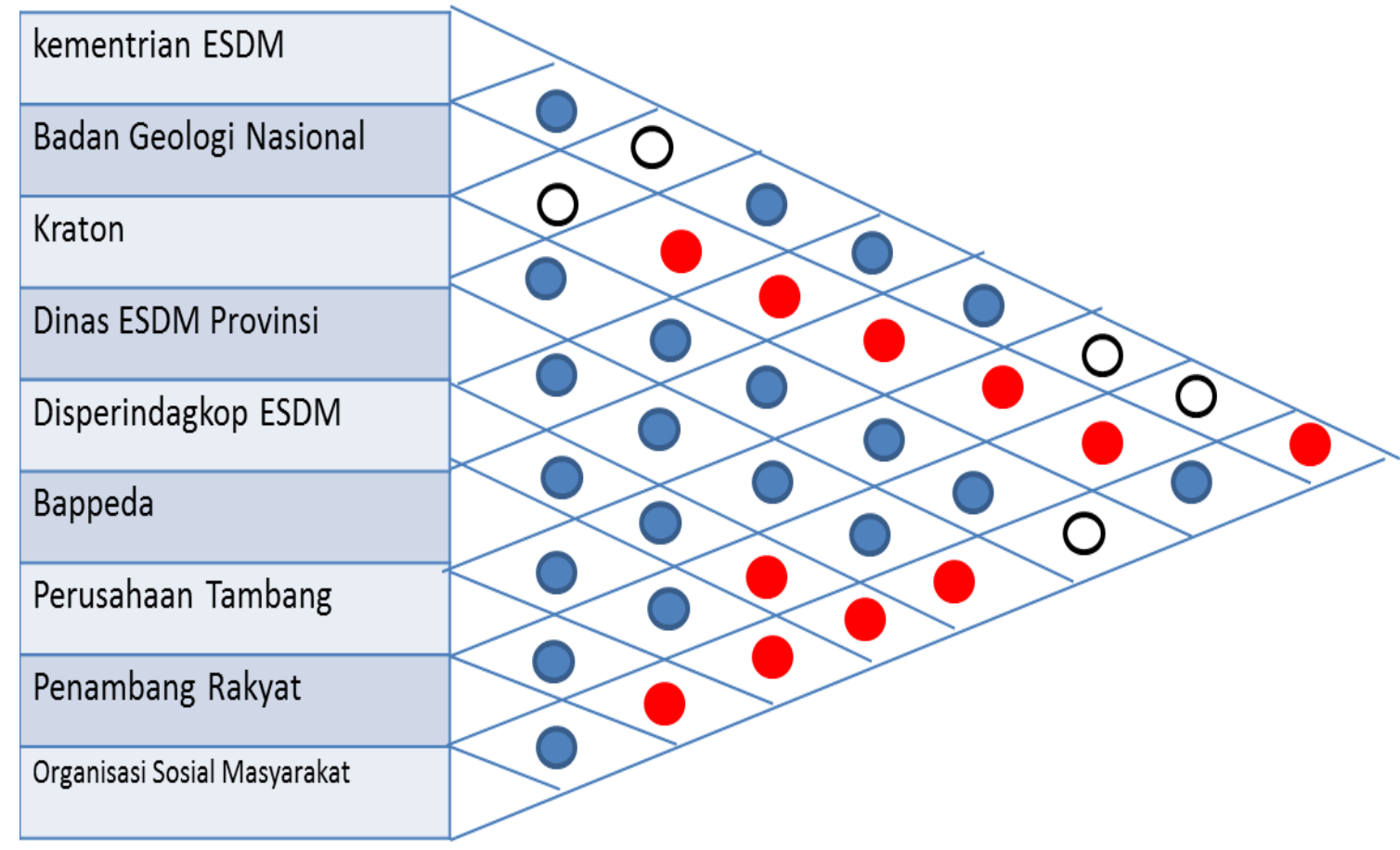

Ket: Matriks relasi organisasi konflik, netral, $\bigcirc$ mendukung

Sumber: Analisis Penulis, 2016

\section{Gambar 1. Matriks Konflik}

Sebagai gambaran, Dinas ESDM Kabupaten Gunungkidul masih memiliki kecenderungan untuk mengizinkan penambangan berjalan dengan alasan mata pencaharian masyarakat dan fakta ini menunjukkan bahwa aktivitas penambangan telah ada sejak dahulu. Selain itu, Dinas ESDM Kabupaten Gunungkidul menyampaikan perihal PAD yang didapatkan daerah dari penambangan tersebut. Batugamping sebagai bahan galian harus dimanfaatkan secara ekstraktif (hasil hearing dengan Disperindagkop ESDM Kabupaten Gunungkidul, 2014). Pemerintah juga belum menunjukan ketegasannya soal penambangan hingga bulan Juni 2015 ketika seluruh penambangan dihentikan.

\section{Analisis Pendekatan Pierre Bourdieu}

\section{Arena}

Arena merupakan suatu ruang hubungan yang karakternya terdiri atas posisi para penghuninya (Emirbayer \& Jhonson, 2008). Di dalam arena terdapat suatu kontestasi antara para aktor dengan modal-modal yang mereka miliki (Swartz, 2002) atau seperti yang didefinisikan oleh Bourdieu (dalam Swartz, 1997; Lubis, 2014) bahwa arena adalah ruang sirkulasi kapital yang dimiliki oleh organisasi yang berada di dalam arena tersebut. Kontestasi dan relasi tersebut dapat diterapkan dalam berbagai kasus dan lapangan. Dengan melakukan pendekatan melalui arena, maka seorang pengamat akan dapat mengetahui cakupan ruang kajian yang dimilikinya (Swartz, 1997). Pemahaman terhadap arena merupakan sebuah pendekatan yang cukup ampuh dalam memberikan analisis terhadap organisasi. Organisasi selalu berada dalam suatu matriks relasi dengan organisasi 
lainnya. Arena dipandang sebagai suatu area kontestasi antara penghuni dalam arena tersebut dalam rangka mengamankan posisi mereka dalam ruang tersebut.

Sebagai suatu ruang kontestasi, maka arena - dalam hal ini arena organisasi dalam penambangan batugamping di Ponjong - merupakan suatu pengaturan dari kekuasaan atau relasi kekuasaan. Kekuasaan dalam konteks ini berhubungan sangat erat dengan kepemilikan kapital. Dalam suatu arena, para aktor yang berada didalamnya akan menginvestasikan kapital dan berebut kapital (Walther, 2014). Kepemilikan kapital akan memberikan pemiliknya untuk hadir dan memiliki pengaruh di dalam suatu arena sehingga analisis terhadap suatu arena dapat dilakukan dengan melakukan kajian terhadap distribusi kapital didalamnya. Arena dapat dianalisis melalui tiga tahap, yakni dengan mengabstraksi setiap lingkungan khusus kepada lingkungan politis, dengan demikian akan didapatkan relasi objektif antar aktor di dalam ranah tersebut dan yang terakhir adalah dengan mencari kebiasaan yang dilakukan setiap aktor dalam ranah tersebut.

Di dalam suatu arena, untuk kemudian menjadi suatu kelompok yang mendominasi kepemiikan, suatu kapital mutlak diperlukan. Bagi mereka yang kemudian memiliki kapital yang spesifik terhadap arena tersebut akan memiliki kekuasan untuk harga relatif dari setiap sumber daya yang ada di dalam arena tersebut. Selain itu, mereka juga dapat memproduksi legitimasi dalam mendistribusi kepada pihak lainnya.

Dalam kasus arena penambangan batugamping di Ponjong, kapital yang berperan penting adalah kapital ekonomi dan kapital kultural. Kapital kultural merupakan kapital yang memegang peranan penting oleh sebab setiap keputusan yang diambil pada kawasan karst merupakan produk dari ruang-ruang ilmiah tempat dimana pengetahuan diproduksi. Seminar, hearing, dan penelitian menjadi dasar dalam menentukan kebijakan dan tindakan pengelolaan terhadap penambangan batugamping di Ponjong. Meskipun demikian, kapital ekonomi merupakan kapital penentu dalam arena ini. Kapital ekonomi menjadi asas utama dalam pengelolaan terutama dalam hal kepemilikan tanah dan keuntungan yang didapat dari kegiatan penambangan batugamping.

Relasi organisasi dalam matriks-matriks yang dibuat pada kegiatan penambangan batugamping di Ponjong merupakan suatu arena. Dalam relasi tersebut terdapat suatu nilainilai yang digunakan sebagai cita-cita dalam memandang objek batugamping di Kecamatan Ponjong. Untuk mencapai kepada nilai tersebut, analisis intraorganisasi akan menggunakan tiga terminologi yakni nilai sebagai tujuan suatu organisasi, fungsi sebagai cara mencapai tujuan tersebut, dan kapital sebagai kekuatan dalam mencapai nilai tersebut.

\section{$\underline{\text { Kapital }}$}

Kapital dalam perspektif Bourdieu tidak sama dengan kapital dalam pandangan Marxisme Bourdieu memperluas definisi kapital yang oleh Marx terpusat pada ekonomi menjadi memliki dimensi kultural dan simbolik (Desan, 2013). Kapital dalam pandangan Bourdieu terbagi dalam beberapa kategori, yakni ekonomi kapital termasuk aset yang langsung dapat dikonversi ke uang, kapital budaya, yakni bentuk kapital yang dapat terinstitusionalisasi dalam bentuk pendidikan atau pengetahuan, dan kapital sosial yang terinstitusionalisasi dalam bentuk kehormatan atau pangkat (nobility) serta dalam bentuk jaringan dan koneksi (lihat juga Fukuyama, 1999). Kapital hanya dapat berfungsi di dalam suatu arena atau dalam relasi interorganisasi dimana dalam konsep Marx bahwa "kapital bukanlah suatu benda (thing) melainkan relasi sosial”. Melalui kapital, pemetaan hubungan kekuasaan dapat dilakukan (Haryatmoko, 2016).

Melalui kapital tersebut, setiap organisasi berpacu untuk mengejawantahkan persepsi mereka atau mengejar nilai mereka. Dengan kapital tersebut, setiap organisasi juga beroperasi melalui fungsi-fungsi mereka yang terbentuk dalam arena. Dalam konteks ekologi politik, kontestasi yang dilakukan dalam arena dilakukan untuk pengelolaan kekuasaan dalam membuat akses ke sumber daya alam. Kontestasi tersebut akan 


\section{Konflik Penambangan Batugamping Kecamatan Pojong dalam Tinjauan Arena Bourdieu}

berlangsung hingga menghasilkan legitimasi dan legalitas (pengakuan) dari organisasi lain. Bentuk kontestasi yang paling umum bisa terlihat adalah penyamaan persepsi lewat pendekatan-pendekatan pengelolaan lingkungan. Pendekatan pengelolaan ligkungan merupakan cara setiap organisasi untuk mendayagunakan kapital yang mereka miliki terhadap organisasi lain. Tabel 5 menjelaskan pemetaan matriks kapital yang dimiliki oleh para organisasi.

Tabel 5. Pemetaan Matriks Kapital yang Dimiliki Oleh para Organisasi

\begin{tabular}{|c|c|c|c|}
\hline Organisasi & $\begin{array}{l}\text { Jenis Kapital } \\
\text { yang dimiliki }\end{array}$ & Cara akumulasi kapital & $\begin{array}{l}\text { Pendekatan } \\
\text { Pengelolaan }\end{array}$ \\
\hline Pemerintah & $\mathrm{E}, \mathrm{C}$ & $\begin{array}{l}\text { Upaya mencarikan alternatif } \\
\text { pekerjaan untuk mengentikan } \\
\text { penambangan }\end{array}$ & $\mathrm{P}, \mathrm{N}$ \\
\hline Kementrian ESDM & $\mathrm{C}$ & Pembuatan peraturan & \\
\hline Badan Geologi Nasional & $\mathrm{C}$ & Kontestasi pengetahuan & \\
\hline Keraton & $\mathrm{C}, \mathrm{S}$ & $\begin{array}{l}\text { Sosial kapital lewat ideologi } \\
\text { feodalistik keraton }\end{array}$ & \\
\hline $\begin{array}{l}\text { Dinas ESDM Provinsi } \\
\text { DIY }\end{array}$ & $\mathrm{C}$ & $\begin{array}{l}\text { Pendataan, penelitian dan } \\
\text { kontestasi pengetahuan }\end{array}$ & \\
\hline Disperindagkop ESDM & $\mathrm{C}$ & - Hearing & \\
\hline Kabupaten Gunungkidul & & - Kontestasi pengetahuan & \\
\hline $\begin{array}{l}\text { Bappeda Kabupaten } \\
\text { Gunungkidul }\end{array}$ & $\mathrm{C}$ & $\begin{array}{l}\text { - Penelitian } \\
\text { - Kontestasi pengetahuan }\end{array}$ & \\
\hline Swasta & & & $\mathrm{E}$ \\
\hline Perusahaan Tambang & $\mathrm{E}$ & $\begin{array}{l}\text { - Menambang dan kegiatan } \\
\text { ekstraktif } \\
\text { - Melakukan upaya pembangunan } \\
\text { desa dan membuka lapangan } \\
\text { pekerjaan melalui aktivitas } \\
\text { penambangan }\end{array}$ & \\
\hline Masyarakat & & & $\mathrm{N}$ \\
\hline Penambang Rakyat & $\mathrm{C}$ & Menambang & \\
\hline $\begin{array}{l}\text { Organisasi Sosial } \\
\text { Masyarakat }\end{array}$ & $\mathrm{S}$ & $\begin{array}{l}\text { Kontestasi pengetahuan melalui } \\
\text { seminar, FGD, hearing }\end{array}$ & \\
\hline
\end{tabular}

Ket: Pada Kolom Jenis Kapital, C: Cultural, E: Economic, S: Social. Pada kolom pendekatan pengelolaan: N: Nasihat, E: Ekonomi, P: Peraturan sesuai dengan tipologi Barrow (1999)

Dari analisis dan asumsi mengenai kapital yang dimiliki oleh masing-masing organisasi, maka organisasi yang paling kuat posisinya dalam arena adalah organisasi yang tergabung di dalam kelompok pemerintah, seperti Kementarian ESDM, Badan Geologi Nasional, Dinas ESDM Provinsi DIY, Disperindagkop ESDM Kabupaten Gunungkidul, dan Bappeda Kabupaten Gunungkidul. Hal ini dikarenakan pemerintah memiliki kapital ekonomi berupa APBN dan APBD, kapital budaya berupa pengetahuan yang diorganisasi dan kapital sosial dengan simbol-simbol. Swasta atau pasar memiliki kapital ekonomi yang sangat besar dan sosial kapital lewat upaya mereka dalam membangun desa lewat kapital ekonomi mereka. Masyarakat memiliki relasi dan solidaritas sebagai kapital sosial yang sangat kuat. Tabel 6 menjelaskan tipologi bentuk-bentuk kapital pada klasifikasi kapital Bourdieu di Penambangan batugamping Kecamatan Ponjong. 
Tabel 6. Tipologi Bentuk-bentuk Kapital pada Klasifikasi Kapital Bourdieu di Arena Penambangan Batugamping Kecamatan Ponjong

\begin{tabular}{|c|c|c|}
\hline Tipe Kapital & Bentuk & Aktor Terkait \\
\hline \multirow{3}{*}{ Ekonomi } & Kepemilikan tanah & $\begin{array}{l}\text { Keraton, penambang rakyat, dan perusahaan } \\
\text { tambang }\end{array}$ \\
\hline & $\begin{array}{l}\text { Alat keruk } \\
\text { batugamping/backhoe }\end{array}$ & Perusahaan tambang \\
\hline & Tenaga kerja & Penambang rakyat dan perusahaan tambang \\
\hline \multirow{3}{*}{ Kultural } & Pengetahuan & $\begin{array}{l}\text { Badan Geologi Nasional, Organisasi Sosial } \\
\text { Masyarakat, } \\
\text { Gunungkidul }\end{array}$ \\
\hline & Gelar akademis & $\begin{array}{l}\text { Badan Geologi Nasional dan Bappeda } \\
\text { Kabupaten Gunungkidul }\end{array}$ \\
\hline & Regulasi dan Perizinan & $\begin{array}{l}\text { Disperindagkoptam ESDM Kabupaten } \\
\text { Gunungkidul, Dinas ESDM Provinsi DIY, } \\
\text { Kementrian ESDM }\end{array}$ \\
\hline Sosial & $\begin{array}{l}\text { Norma kooperatif } \\
\text { Jaringan }\end{array}$ & $\begin{array}{l}\text { Penambang rakyat } \\
\text { Organisasi sosial masyarakat }\end{array}$ \\
\hline
\end{tabular}

Sumber: Hasil Analisis, 2016

Selain berada pada basis-basis kapital budaya yang beroperasi pada koridor hegemoni, kekuatan pemerintah juga terdapat pada aparatus-aparatus yang beroperasi pada koridor koersi. Negara memiliki polisi, tentara, dan aparatus-aparatus yang memiliki legitimasi koersif untuk melakukan pengaturan (governmentality) dengan kekerasan. Adanya basis kekuatan koersif tersebut semakin meguatkan peran negara dalam kontestasi tersebut. Hal tersebut dapat tercermin dari kepatuhan penambang terhadap peraturan yang dibuat. Dari studi persepsi didapatkan bahwa perusahaan tambang, meskipun memiliki kapital ekonomi yang besar, menunjukan kepatuhan terhadap peraturan.

\section{Pengelolaan Lingkungan, Persepsi, Nilai, dan Kapital}

Setelah mendefinisikan arena dengan mengkaji relasi dan kontestasi modal yang ada di arena penambangan batugamping di Kecamatan Ponjong, maka dapat dilihat bagaimana dalam arena tersebut, persepsi, nilai dan kapital berkaitan dengan pengelolaan atau manajemen lingkungan. Pengelolaan lingkungan, dalam konteks ekologi politik merupakan suatu bentuk kepengaturan untuk membagi kepengaturan dalam hal sumber daya alam. Secara metodologis, ekologi politik terpusat pada pertanyaan mengenai: (i) siapa mengontrol apa, (ii) siapa yang mempunyai kekuasaan memutuskan tentang apa, dan (iii) siapa yang diharapkan melakukan tugas (Robbins, 2004: 201). Oleh sebab itu, konflik dalam lingkungan diawali dengan mulai adanya pembagian kerja yang berujung kepada diferensiasi aktor dalam arena-arena. Pembagian kerja tersebut didasarkan kepada kapital yang dimilikinya dan persepsi yang diambil oleh para aktor tersebut.

Dalam melakukan pengambilan posisi, kapital memegang peranan yang vital. Semakin banyak modal yang dimiliki, maka pemangku kepentingan akan memiliki kekuatan lebih untuk melakukan pengambilan-posisi tersebut. Posisi yang diambil dalam suatu arena juga akan memberikan kekuasaan kepengaturan dalam arena tersebut. Batugamping, memiliki berbagai nilai yang akan tertransformasi menjadi persepsi. Dari nilai tersebut, muncul kontestasi dalam pengelolaan lingkungan untuk menentukan bagaimana batugamping sebagai suatu sumber daya terdistribusi dan dapat dimanfaatkan sesuai dengan keinginan para pemangku kepentingan atau aktor-aktor yang ada dalam suatu arena. 


\section{Konflik Penambangan Batugamping Kecamatan Pojong dalam Tinjauan Arena Bourdieu}

Persepsi berhubungan dengan ideologi serta cara berpikir yang dimiliki oleh setiap pemangku kepentingan dalam arena (Brubaker, 1985). Persepsi tersebut yang berkaitan dengan pilihan dan setiap manajer lingkungan dan merupakan sumber dari konflik lingkungan (Lach, 1996). Dalam konteks Bourdieu, persepsi setiap pemangku kepentingan akan mengambil apa yang disebut sebagai pembedaan (difference) dan dari pembedaan tersebut, setiap aktor melakukan pengambilan-posisi (position-taking) secara sosial (Bourdieu, 1977) berdasarkan kapital yang mereka miliki (Haryatmoko, 2016).

Di sini, terdapat dua terminologi yang cukup menentukan, yakni persepsi dan kapital. Lewat kedua terminologi ini, alternatif dalam menangani konflik dapat dilihat dengan lebih mudah terlebih lewat kacamata arena Bourdieu. Setiap aktor atau pemangku kepentingan diarahkan untuk menempati posisi mereka dalam arena dan disuesuaikan dengan upaya pembedaan dari masing-masing aktor tersebut. Selain itu, setiap aktor harus diakomodir dalam menanamkan kapitalnya dan dilindungi haknya untuk mengekstraksi kapital dari suatu arena. Kebijakan untuk menetapkan bentang alam karst dan pemanfaatan telah diatur dalam Peraturan Pemerintah 17 tahun 2012 tentang Penetapan Kawasan Bentang Alam Karst.

\section{Kesimpulan}

Kawasan karst merupakan suatu kawasan yang berpotensi besar terhadap penambangan batugamping sebagai suatu potensi bahan galian yang rawan akan terkait lingkungan. Permasalahan penambangan batugamping di Kecamatan Ponjong merupakan sebuah konflik manajemen lingkungan. Konflik dalam lingkungan diawali dengan adanya pembagian kerja yang berujung kepada diferensiasi aktor dalam arena-arena. Arena penambangan batugamping Ponjong menjadi suatu arena yang diisi oleh aktor-aktor dari berbagai stakeholder, meliputi pemerintah, pihak swasta, dan masyarakat. Pembagian kerja tersebut didasarkan kepada kapital yang dimilikinya dan persepsi yang diambil oleh para aktor tersebut. Aktor-aktor tersebut menjadi bermakna dalam upaya berkontestasi dalam arena penambangan batugamping di Kecamatan Ponjong. Kapital memegang peranan yang vital. Semakin banyak modal yang dimiliki, maka pemangku kepentingan akan memiliki kekuatan lebih untuk melakukan pengambilan posisi. Jika dilihat dari kapital yang dimiliki, organisasi yang memiliki kapital kuat adalah organisasi yang tergabung di dalam kelompok pemerintah karena pemerintah memiliki kapital ekonomi berupa APBN dan APBD, kapital budaya berupa pengetahuan yang diorganisasi dan kapital sosial dengan simbol-simbol. Di samping itu, masing-masing pemangku kepentingan atau aktor yang berperan tersebut memiliki kapital dan berupaya mengakumulasi kapital tersebut untuk mencapai kapital utama: penguasaaan sumber daya alam batugamping di Kecamatan Ponjong.

Setiap aktor atau pemangku kepentingan perlu diarahkan untuk menempati posisi masing-masing dalam arena dan disuesuaikan dengan upaya pembedaan dari masingmasing aktor tersebut. Selain itu, setiap aktor harus diakomodir dalam menanamkan kapitalnya dan dilindungi haknya untuk mengekstraksi kapital dari suatu arena. Pemahaman terhadap arena yang baik akan memunculkan pemahaman terhadap motivasi dan struktur yang bekerja pada setiap aktor. Dengan demikian, proses negosiasi antar aktor akan dapat lebih mudah dilakukan dan permasalahan persepsi akan lebih mudah dijembatani. 


\section{Daftar Pustaka}

Adib, M. (2012). Agen dan struktur dalam pandangan Pierre Bourdieu. Biokultur, 1(2), 91-110.

Barrow, C. J. (1999) Environmental management: Principle dan practice. London: Routledge.

Benson, R. (1999). Field theory in comparative context: A new paradigm for media studies. Theory and Society, 28(3), 463-498. doi:10.1023/a:1006982529917.

Bourdieu, P. (1996). Distinction: A social critique of the judgement of taste. Chicago: Harvard University Press.

Bourdieu, P. (1977). Outline of a theory of practice. USA: Cambridge University Press.

Brubaker, R. (1985). Rethinking classical theory: The sociological vision of Pierre Bourdieu. Theory and Society, 14(6), 745-775. doi:10.2307/657374.

Cahyono, S. A., \& Susanti, P. D. (2013). Persepsi stakeholder terhadap penambangan gamping di Kecamatan Ponjong Kabupaten Gunungkidul Yogyakarta. In Sudarmadji, E. Haryono, T. N. Adji, Widyastuti, R. Harini, E. Nuriani, A. Cahyadi, \& H. Nugraha (Eds.), Ekologi Lingkungan Kawasan Karst Indonesia (pp. 156-165). Yogyakarta: Kelompok Studi Karst Fakultas Geografi UGM.

Couldry, N. (2003). Media meta-capital: Extending the range of Bourdieu's field theory. Theory and Society, 32, 653-677. doi:10.1023/B:RYSO.0000004915.37826.5d.

Desan, M. H. (2013). Bourdieu, marx, and capital: A critique of the extension model. Sociological Theory, 31(4), 318-342. doi:10.1177/0735275113513265.

Emirbayer, M., \& Jhonson, V. (2008). Bourdieu and organizational analysis. Theory and Society, 371), 1-44. doi:10.1007/s11186-007-9052-y.

Fukuyama, F. (1999). The great disruption: Human nature and the reconstitution of social order. New York: Free Press.

Haryatmoko. (2016). Membongkar rezim kepastian: Pemikiran kritis post strukturalis. Yogyakarta: Kanisius.

Lach, D. (1996). Introduction: Environmental conflict. Sociological Perspectives, 39(2), 211-217. doi:10.2307/1389308.

Lubis, A. Y. (2014). Postmodernisme: Teori dan metode. Jakarta: Rajawali Press.

Menteri Energi dan Sumber Daya Mineral Republik Indonesia. (2004). Keputusan Menteri Energi dan Sumber Daya Mineral Nomor 1659.K/40/MEM/2004 tentang Penetapan Kawasan Karst Gunung Sewu dan Pacitan Timur. Jakarta: Kementerian Energi dan Sumber Daya Mineral Republik Indonesia.

Menteri Energi dan Sumber Daya Mineral Republik Indonesia. (2012). Peraturan Pemerintah 17 Tahun 2012 tentang Penetapan Kawasan Bentang Alam Karst. Jakarta: Kementerian Energi dan Sumber Daya Mineral Republik Indonesia.

Moore, J. D. (2009). Vision of culture: An introduction to anthropological theory and theorists. Plymouth: Altamira Press.

Presiden Republik Indonesia. (2008). Peraturan Pemerintah Nomor 26 Tahun 2008 tentang Rencana Tata Ruang Wilayah Nasional. Jakarta: Kementerian Hukum dan Hak Asasi Manusia Republik Indonesia.

Robbins, P. (2004). Political ecology. A critical introduction. Oxford: Blackwell Publishing.

Samodra, H. (2001). Nilai strategis kawasan karst di Indonesia: Pengelolaan dan Perlindungan. Bandung: Pusat Penelitian dan Pengembangan Geologi, Badan Geologi Departemen Energi dan Sumberdaya Mineral.

Satmoko, A. R. (2005). Kerusakan lahan akibat penambangan batugamping di kawasan karst Desa Bedoyo dan Karangasem Kecamatan Ponjong Kabupaten Gunungkidul Propinsi Daerah Istimewa Yogyakarta (Unpublished master's thesis). Program Studi Ilmu Lingkungan, Sekolah Pascasarjana, Universitas Gadjah Mada, Yogyakarta.

Sutikno. (2001). Pemanfaatan sumberdaya kawasan karst untuk tujuan ekonomi. Paper presented at Seminar Potensi Ekonomi Daerah Karst, Yogyakarta.

Swartz, D. (1997). Culture and power: The sociology of Pierre Bourdieu. Chicago: University of Chicago Press.

Swartz, D. (2002). The sociology of habit: The perspective of Pierre Bourdieu. The Ocupational Therapy Journal of Research, 22, 61-69. doi:10.1177/15394492020220\$108. 


\section{Konflik Penambangan Batugamping Kecamatan Pojong dalam Tinjauan Arena Bourdieu}

Walther, M. (2014). Repatriation to France and Germany. Comparative study based on bourdieu's theory of practice. Brussels, Belgium: Springer Gable.

Widyastuti. (2007). Pengaruh penambangan batugamping terhadap kualitas air tanah di Kecamatan Ponjong (Unpublished master's thesis). Program Studi Ilmu Lingkungan, Sekolah Pascasarjana, Universitas Gadjah Mada, Yogyakarta.

Wuspada, R. D., Purnaweni, H., \& Sasongko, D. P. (2012). Implementasi kebijakan pelarangan penambangan di kawasan karst Kabupaten Gunungkidul. Prosiding Seminar Nasional Pengelolaan sumberdaya Alam dan Lingkungan. Retrieved from http://eprints.undip.ac.id/37610/1/13-Dewi_Wuspada.edited..pdf. 